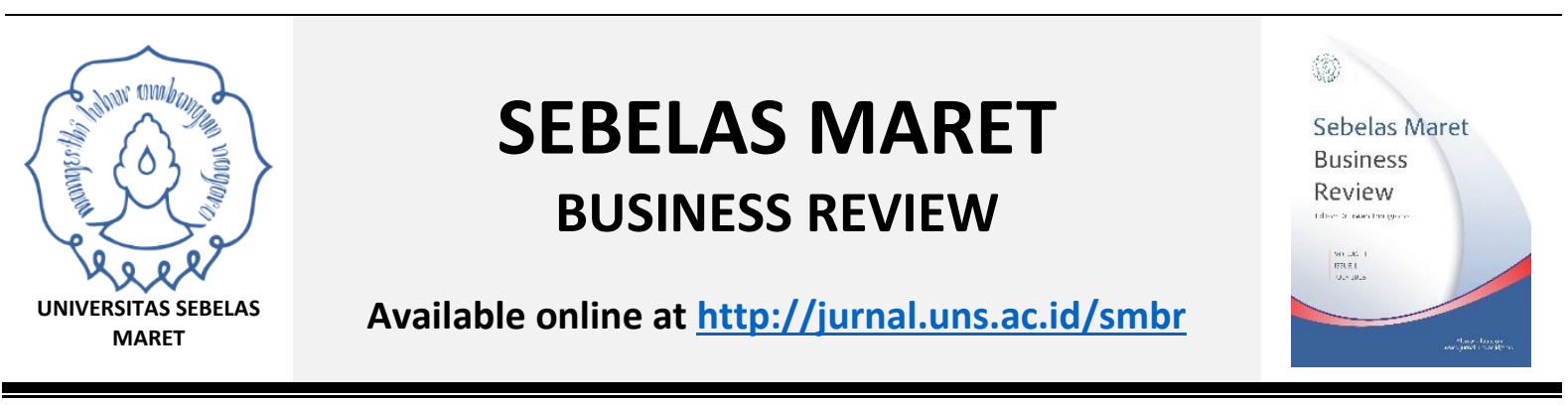

\title{
Creative People as a New Source of Competitive Advantage in the Creative Industry
}

\author{
Eriana Astuty ${ }^{1 *}$, Suryana ${ }^{2}$ \\ ${ }^{1}$ Department of Business \& Management, Universitas Widyatama \\ Jl. Cikutra 204A, Bandung, Indonesia \\ 2) Doctoral Program of Management Science, \\ Universitas Pendidikan Indonesia \\ Jl. Dr. Setiabudhi No. 229, Bandung, Indonesia \\ ${ }^{*}$ Corresponding Author: eriana.astuty@widyatama.ac.id (+6282117170831)
}

\begin{tabular}{|c|c|}
\hline ARTICLE INFO & ABSTRACT \\
\hline Article History: & $\begin{array}{l}\text { Today's development of creative industries in the economy } \\
\text { of Indonesia has shown a significant improvement. }\end{array}$ \\
\hline $\begin{array}{l}\text { Received } 16 \text { September } \\
\quad 2017\end{array}$ & $\begin{array}{l}\text { Creative industries have contributed in improving the } \\
\text { growth of Gross Domestic Product (GDP), employment }\end{array}$ \\
\hline $\begin{array}{l}\text { Received in Revised } \\
\text { Form }\end{array}$ & $\begin{array}{l}\text { opportunities, and national industries. Unfortunately, } \\
\text { those improvements are not in line with their internal }\end{array}$ \\
\hline $\begin{array}{l}\text { Accepted } 14 \text { December } \\
2017\end{array}$ & $\begin{array}{l}\text { developments. The purpose of this study is to find the } \\
\text { answer of the gap phenomenon that occurred. It is found }\end{array}$ \\
\hline $\begin{array}{l}\text { Available online } 8 \\
\quad \text { January } 2018\end{array}$ & $\begin{array}{l}\text { that only three sub-sectors out of } 15 \text { have positive } \\
\text { contributions as mentioned above. They include craft, } \\
\text { fashion, and culinary. Primary data were obtained through }\end{array}$ \\
\hline Keywords: & $\begin{array}{l}\text { a questionnaire survey and observation carried out in batik } \\
\text { and woven-fabric business units in } 6 \text { provinces in }\end{array}$ \\
\hline Creative people, & Indonesia. By surveying 30 units of batik and woven-fabric \\
\hline Innovation, Competit & business in 6 provinces in Indonesia, it is found that \\
\hline Advantage, Creat & creative people as renewable resources have been able to \\
\hline Industries & $\begin{array}{l}\text { improve Indonesia competitive advantage in crafts } \\
\text { industries by reflecting local culture and heritage through } \\
\text { creativity on various innovations. }\end{array}$ \\
\hline
\end{tabular}




\section{INTRODUCTION}

The concept of creative economy is originated from a process of people's use of their creative imagination, so-called creativity as a human resource, to increase an idea's value and is set on knowledge-based in which the national heritage and technology are parts of the development (Kementerian Pariwisata dan Ekonomi Kreatif RI, 2014). Creativity is also defined as an act of creating or producing unique new things, ideas, alternatives that may be useful in problem-solving that allows individuals to think outside the box which powers innovation in other sectors and improves the quality of life.

Creativity, innovation, and invention are main factors in economic activities. In the 18th century, The Industrial Revolution led to the transformation of the economy that was originally dominated by agriculture sector which was based on human and natural resources into an economy dominated by capital-based industries. In the 1950s, the economy was driven by knowledge as its central resource in the creation of added value. Then in 1995, there was a globalization of creativity-based industries that made the creative economy grow in line with the development of information technology; it is called the 4th wave (Howkins, 2002). Creative thinking in the future becomes very important because there has been a shift in the needs of society (Pink, 2005). In the eighteenth to the twentieth centuries, individuals were confronted with limitations so that the required workforce was people who worked with sequential, literal, functional, textual and analytic work. However, now and in the future aesthetic, contextual, synthesis, and visualization skills are believed to be essential capabilities in driving the economy and creating a better quality of life for society.

Currently, creative economy in Indonesia is driven by 15 creative industry subsectors that have the potential to be developed as a leading sector that can enhance competitiveness and high economic growth and inclusive or wide-ranging. The 15 creative industries sub-sectors that are developing in Indonesia are: (1) architecture, (2) design, (3) film, video, and photography, (4) culinary, (5) craft, (6) fashion, (7) music, 8) publications, (9) interactive games, (10) advertising, (11) research and development, (12) art, (13) performing arts, (14) information technology, and (15) television and radio. The development of creative industry has gained government attention in the last 10 (ten) years because the creative industry has been able to contribute $7.05 \%$ to the national GDP. It has also contributed $10.72 \%$ to the total absorption of Indonesian workforces in 2013 (Kementerian Pariwisata dan Ekonomi Kreatif RI, 2014).

Surprisingly, the state of the creative industry development and its contribution to the national economy of Indonesia are opposed to the internal development of the creative industry itself. This is reflected in the fact that not all creative industries contribute positively to the above, only three out of 15 creative industries in Indonesia contribute as mentioned above. The sub-sectors of the creative industry are craft, fashion, and culinary, with $32.5 \%, 28,3 \%$, and $14.4 \%$ contribution to the GDP, respectively. Three largest sub-sectors also contribute around $90 \%$ of employment in the creative industry. A question why there are only 3 out of 15 creative industries showed the remarkable contribution to the Indonesian economy had become the background of the research.

Based on intensive research and discussion with all stakeholders, the current state of creative industry in Indonesia is faced with seven strategic issues that must be considered in its development (Ardhala, Santoso, \& Sulistyarso, 2016; Arifin \& Sugiyanto, 2015; Aritenang, 2015; Hutabarat \& Zoel, 2012; Kementrian Pariwisata dan Ekonomi Kreatif RI, 2014; Utami \& Lantu, 2014). These issues are: (1) The availability of creative, professional, and competitive human resources; (2) The availability of qualified, diverse, 
and competitive raw materials; (3) Development of a competitive, growing and diverse industry; (4) Availability of compatible, accessible, and competitive financing; (5) Market expansion for works, businesses, and creative people; (6) Availability of suitable and competitive infrastructure and technology; And (7) Encouraging institutional and business climate to the development of creative industries.

\section{LITERATURE REVIEW}

\section{Creative People, Technology}

The development of the creative industry is based on the development of creative people as individual competencies so that in the future the company will be successful if it does not only focus on technology and market development, but also pays attention to human resource development (Kamprath \& Mietzner, 2015). This has become one of the obstacles to the development of creative industry in Indonesia. It is found that the factor of creativity is an urge in the development of creative industries in Indonesia. The workforce in the creative industry is extremely weak either in bargaining power or delivering the company's profit. Thus, it needs Indonesian government to help improve it (Arifin \& Sugiyanto, 2015).

In line with this study, Ardhala et al. (2016) also state that creative people are the basic competence of creativity in the creative industry, as well as technical support, IT, government policy, and training are needed to develop creative industry in Indonesia. This is reinforced by the results of research on creative industries in Riau Province, which suggest that human resources are an important factor in the formation of local creative industries in Riau Province (Hutabarat \& Zoel, 2012). Another study suggests that direct and indirect leadership affect individual creativity in the creative industry (Murphy, 2016). In addition to the factors above, there are also other things that are important to be developed in the creative industries of Indonesia as they are related with the improvement of internal capabilities of creative industries in Indonesia, including product development factors. Competitiveness is a comprehensive concept. There are three dimensions included in the concept of competitiveness: (1) potential dimensions, (2) process dimensions, and (3) performance dimensions. Potential dimensions comprise the factors needed to develop the business, ranging from the owner and firm characteristics that are influenced by internal capabilities and the external environment. The process dimensions comprise an operating strategy involving effective technology factors, as well as a useful growth strategy. Performance dimensions are divided into financial performance and non-financial performance (Utami \& Lantu, 2014).

\section{Innovation}

Product development, a part of the innovation process as a result of creativity, also plays an important role in developing the creative industry. Internal capabilities and external environment, effective business strategies and processes, and positive corporate performance are three comprehensive dimensions for the development of creative industry competitiveness in Indonesia (Utami \& Lantu, 2014). Product development factors become parts of innovation that are originated from creative people. Kementerian Pariwisata dan Ekonomi Kreatif RI (2014) states that creativity is a renewable resource and it may be endless if the abundant of Indonesian human resources are creative and able to create added value supported by encouraging environment. This statement is supported by previous research which says that diversification of corporate products and various geographical factors in multinational corporations, as well as their 
relation to the internationalization process play an important role (Batsakis \& Mohr, 2016). Also, it is necessary to improve the internal capabilities of the creative industry in Indonesia. The reason why it is important is based on research from other countries that says that internal capability related to product development becomes quite fundamental. It is also stated that product policy and market-focus are closely related to the process of innovation or product innovation itself as it becomes an important stimulus for international expansion (Bell, Crick, \& Young, 2004).

Regarding innovation, it is found that innovation can mediate the relationship between entrepreneurship and company performance in the creative industries (Parkman, Holloway, \& Sebastiao, 2012). In another study of innovation in the form of product differentiation, it is found that only about $15 \%$ of small companies are projected to pursue international markets. This is because those small companies have experienced international growth that bring a small company into the regional and international markets, and because they make efforts to market internationally (Baum, Schwens, \& Kabst, 2015).

\section{Competitive Advantage}

Competitive advantage arises when a company can create better economic value than its competitors (Barney \& Hesterly, 2015). Based on time consideration, competitive advantage is divided into two: (1) a temporary competitive advantage that lasts in a concise time, and (2) a sustainable competitive advantage that can last longer (Barney, 1991). The creativity factor is apparently a trigger in the economic and social changes that can further become one of the renewable resources in the formation of a company's competitive advantage (Wiryono et al., 2015)

Based on the description above, the author models the research paradigm as follows:

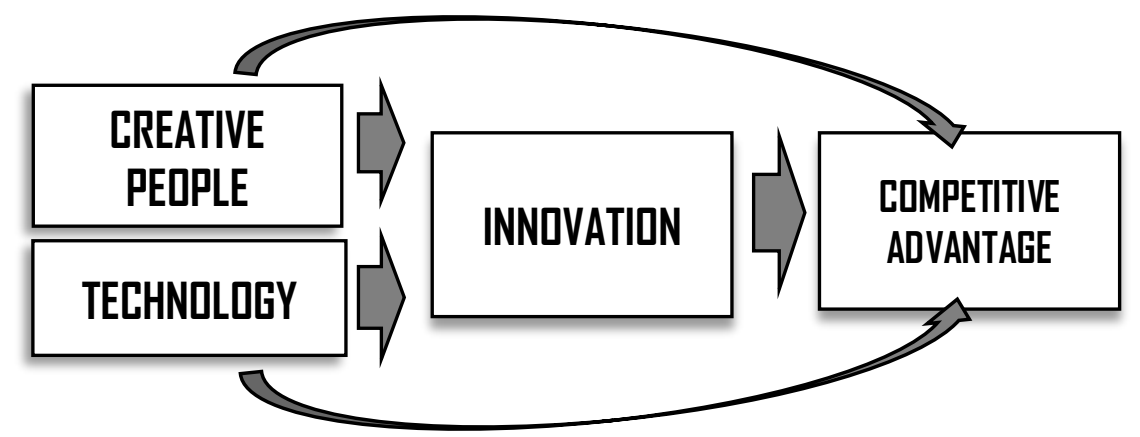

Figure 1. Research Model

\section{Problem Statement}

Considering several theoretical studies that become the reference and the background of this research, the author formulated several problems to be studied such as (1) What are the characteristics, relationships, and influence of creative people either directly or indirectly on competitive advantage in creative industries in Indonesia? (2) What are the characteristics, relationships, and the influence of technology both directly and indirectly in the emergence of competitive advantage in creative industries in Indonesia? (3) How are the relationship and influence of innovation on the sustainable competitive advantage, and what are the significant innovation characteristic in 
developing Indonesian creative industry? (4) What economic value is significant and emerges as a competitive advantage for the creative industries in Indonesia?

This research will only observe one of the three creative industry sub-sectors in Indonesia that excel in contributing to the national GDP, in absorbing workforce, in the ability to develop its business unit, namely craft sub-sector, especially in batik and woven-fabric which are the pride of Indonesia.

\section{METHODOLOGY}

This study is a survey research targeted at the creative industry in Indonesia, mainly focuses on craft sub-sector. The primary data was obtained using survey and the questionnaires were administered randomly. An analysis of secondary resources has been carried out which generate a list of relevant issues for the research objectives issued by several relevant authorities. In this research, the objects to be studied are creative people, technology, innovation, and competitive advantage in Indonesian craft industry. The target population in this study is one of the three sub-sectors of creative industries in Indonesia which has the most significant contribution to the National Gross Domestic Income, has a high employment capability, and is able to create high business opportunities: craft business unit.

The samples withdrawn in this research are 30 craft business units spread in Java, Bali and Nusa Tenggara. Samples that take part in the survey are selected by using random sampling technique. The research instrument used in this study is a questionnaire that contains a list of questions with the assessment of Likert Scale 1-5. The data processing method is descriptive quantitative and verificative using IBM SPSS Statistics 22 and IBM SPSS AMOS 20.

\section{RESULT AND DISCUSSION}

The data was obtained by distributing 30 questionnaires to the samples of batik and woven fabric business units from several cities in 6 provinces in Indonesia. As many as $100 \%$ of respondents are willing to participate in this study with the distribution of $57 \%$ of male respondents and $43 \%$ of female respondents from both craftsmen of batik and woven fabric. The distribution of participants consisted of $13 \%$ of craftsmen from DKI Jakarta, 27\% of craftsmen from West Java, 43\% of craftsmen from Central Java, 3\% craftsmen from Yogyakarta DIY, 7\% craftsmen from Bali, and 7\% craftsmen from NTT province. The observed business units are $80 \%$ of batik business units and $20 \%$ of woven-fabric business units.

\section{Measurement Model}

After running measurement model at each variable and at the stage of the full early model, indicators from each of invalid variables culminated in unreliable data obtained. Then, after revising the model by excluding some items of invalid questions from each variable, the measurement model was re-built by using AMOS 20 in order to obtain the measurement model that is entirely valid and reliable for use in this research. 


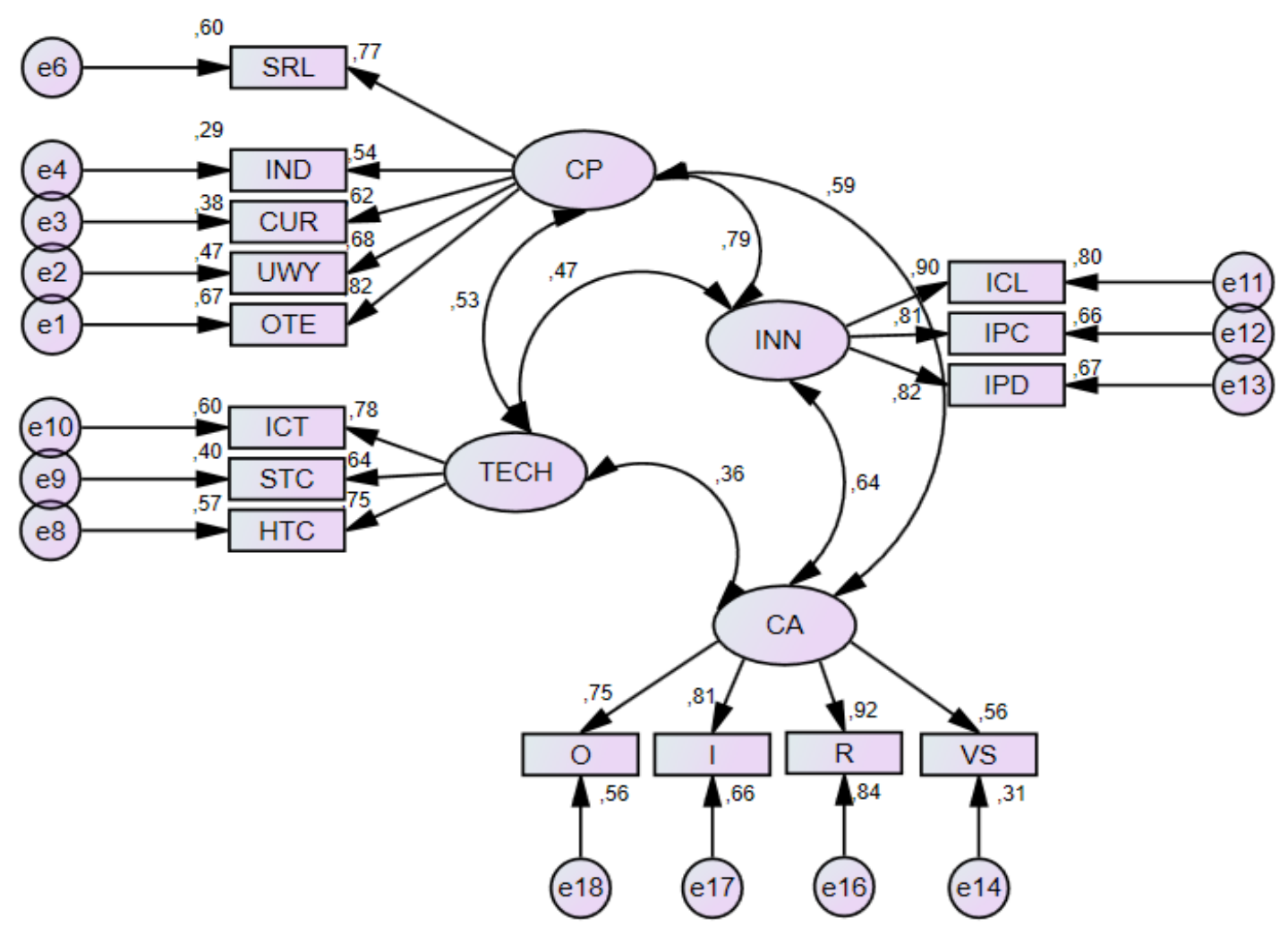

Figure 2. Measurement model

Based on the measurement model obtained, some valid and reliable indicators on each variable that become an object in this research are as follows:

To test the validity, loading factors $(\lambda)$ measurements are required and significant at the real level. It is said to be valid if: loading factors are $\geq 0.5$ and significant at the real level $\alpha$. The results of measurement using Amos 20.0 are: (1) loading factor $(\lambda)$ value of each indicator on creative people, technology, innovation, and competitive advantage in this research is $\geq 0.5$. (2) All indicators on creative people, technology, innovation, and competitive advantages are tested significantly at the $5 \%$ of confidence level ( $p$-value *** $\leq 0.05)$. Thus, it can be concluded that the data on creative people, technology, innovation, and competitive advantages are valid.

For measurement of the reliability test, the value of Construct Reliability (CR) and Variance Extract (VE) are required. It says that it is a good reliability if $C R \geq 0.7$ and $V E \geq 0.5$, and it says that reliability can be accepted if $0.6 \leq \mathrm{CR} \leq 0.7$ and the indicators have good validity (Hair, Black, Babin, \& Anderson, 2014). To calculate CR and VE the author uses the formula:

$C R=\frac{(\Sigma \lambda)^{2}}{(\Sigma \lambda)^{2}+\Sigma e}$

in which $\Sigma e=\Sigma\left(1-\lambda^{2}\right)$ (Hair, Black, Babin, \& Anderson, 2014)

$V E=\frac{\Sigma \lambda^{2}}{\Sigma \lambda^{2}+\Sigma e}($ Gunarto, 2013) 
Table 1 . Result of validity and reliability data processing

\begin{tabular}{llll} 
VARIABLE/ & $\boldsymbol{\Lambda}$ & CR & VE \\
INDICATOR & & & \\
\hline
\end{tabular}

\begin{tabular}{|c|c|c|c|c|}
\hline $\begin{array}{l}\text { CREATIVE PEOPLE (CP) } \\
\end{array}$ & & 0.8 & 0.5 & \\
\hline - Openness to experience & 0.789 & & & Valid \\
\hline $\begin{array}{l}\text { - See things from different } \\
\text { angles/perspectives }\end{array}$ & 0.657 & & & Valid \\
\hline - Curiosity & 0.609 & & & Valid \\
\hline $\begin{array}{l}\text { - Independent in making judgment, } \\
\text { opinions, and actions }\end{array}$ & 0.591 & & & Valid \\
\hline - Independent & 0.805 & & & Valid \\
\hline TECHNOLOGY (TECH) & & 0.8 & 0.5 & \\
\hline $\begin{array}{l}\text { Using hard technologies such as } \\
\text { production machines, CAD/CAM, etc. }\end{array}$ & 0.769 & & & Valid \\
\hline - Using soft technologies such as TQM/JIT & 0.621 & & & Valid \\
\hline - Using computer-based IT & 0.772 & & & Valid \\
\hline INNOVATION (INN) & & 0.9 & 0.7 & \\
\hline - Culture of innovation is created & 0.878 & & & Valid \\
\hline - Innovation process takes place & 0.821 & & & Valid \\
\hline - Product innovation takes place & 0.831 & & & Valid \\
\hline COMPETITIVE ADVANTAGE (CA) & & 0.8 & 0.6 & \\
\hline - Ability to make use of the opportunity & 0.548 & & & Valid \\
\hline $\begin{array}{l}\text { Ability to create products that are not } \\
\text { produced by competitors. }\end{array}$ & 0.941 & & & Valid \\
\hline $\begin{array}{l}\text { - Ability to create products that are not } \\
\text { easily copied }\end{array}$ & 0.812 & & & Valid \\
\hline $\begin{array}{l}\text { - Policy and procedure of company } \\
\text { encourages competitive advantage }\end{array}$ & 0.717 & & & Valid \\
\hline
\end{tabular}

Source: The result of data processing by using AMOS 20

In order to test the validity, loading factors $(\lambda)$ measurements are required and significant at the real level. It is said to be valid if: loading factors are $\geq 0.5$ and significant at the real level $\alpha$. The results of measurement using Amos 20.0 are: (1) loading factor $(\lambda)$ value of each indicator on creative people, technology, innovation, and competitive advantage in this research is $\geq 0.5$. (2) All indicators on creative people, technology, innovation, and competitive advantages are tested significantly at the $5 \%$ of confidence level ( $\mathrm{p}$-value ${ }^{* * *} \leq 0.05$ ). Thus, it can be concluded that the data on creative people, technology, innovation, and competitive advantages are valid.

For measurement of the reliability test, the value of Construct Reliability (CR) and Variance Extract (VE) are required. It says that it is a good reliability if $C R \geq 0.7$ and $V E \geq 0.5$, and it says that reliability can be accepted if $0.6 \leq \mathrm{CR} \leq 0.7$ and the indicators have good validity (Hair, Black, Babin, \& Anderson, 2014). To calculate CR and VE the author uses the formula:

$C R=\frac{(\Sigma \lambda)^{2}}{(\Sigma \lambda)^{2}+\Sigma e}$

in which $\Sigma e=\Sigma\left(1-\lambda^{2}\right)$ (Hair, Black, Babin, \& Anderson, 2014) 
$V E=\frac{\Sigma \lambda^{2}}{\Sigma \lambda^{2}+\Sigma e}($ Gunarto, 2013)

Based on the measurement results using Amos 20.0, it was found that all CR values on creative people, technology, innovation, and competitive advantage are $\geq 0,7$ and all VE values in creative people, technology, innovation, and competitive advantage are $\geq 0.5$. Therefore, it can be concluded that all data on creative people, technology, innovation, and competitive advantages are reliable.

\section{Structural Model}

Structural Equation Modeling (SEM), is the most common and widely used statistical modeling technique. SEM can be demonstrated as a combination of factor analysis, regression analysis, and path analysis (Hair et al., 2014). This study aims to prove and analyze the effect of exogenous variables on endogenous variables. The effect is very complex, where there are independent variables, intermediate variables and dependent variables. These variables are latent variables formed by several indicators (observed variables). Therefore, to analyze the data, this study used technical analysis of Structural Equation Modeling (SEM) using IBM SPSS AMOS program package.

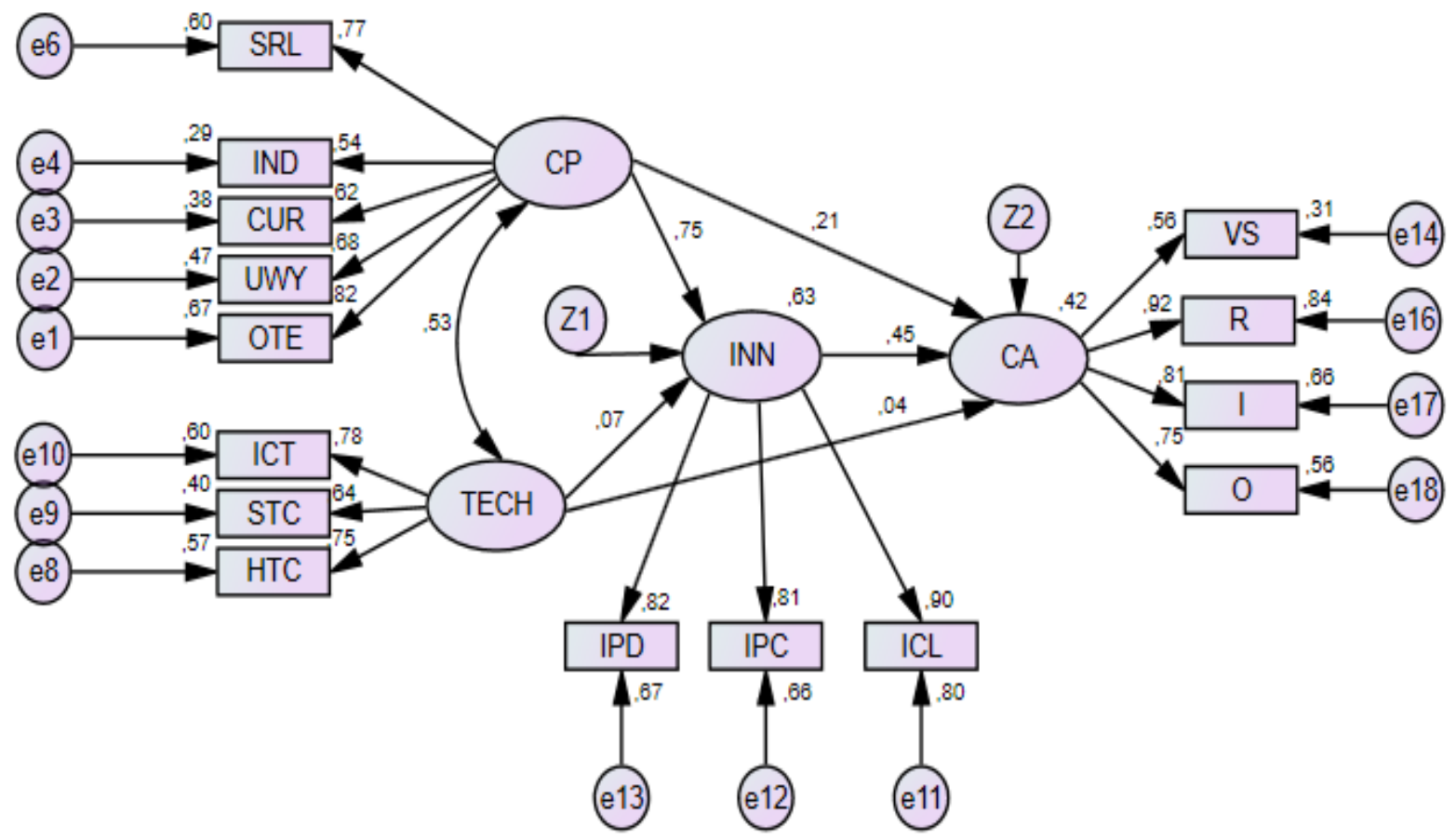

Figure 3. Structural Model

Source: The result of data processing by using AMOS 20, 2017

The goodness of Fit (GOF) values obtained from the above structural model show unfit results between the model and the data. Obtained significance probability value $\mathrm{X} 2$ $=178,005 \mathrm{df}=84$ with $\mathrm{p}=0,000, \mathrm{GFI}$ value $=0,814, \mathrm{AGFI}=0,734, \mathrm{CFI}=0,867$. These GOF values still do not meet the fit criteria. As for direct and indirect influence obtained from the results of the above structural model running, it shows significant results as follows:

From the result of the measurement of the influence of exogenous variables on endogenous variables either directly or through intervening variable, it is clear that creative people play an important role in the emergence of innovation in the business unit of batik and woven fabric that is equal to $75 \%$. Even to the competitive advantage, creative people are proven to give a relatively big influence $(55 \%)$ than the influence of 
other exogenous variables (in this study is the technology variable). Variable of creative people will contribute greatly to the value of competitive advantage if it is mediated by innovation. Directly, creative people will only affect $21 \%$ to competitive advantage, while creative people who bring up the innovation will be able to increase competitive advantage about $34 \%$.

Table 2. Direct, Indirect, and Total Effects

\begin{tabular}{lrrr}
\hline & Technology & Creative People & Innovation \\
\hline Direct Effects & & & \\
Innovation & 0,074 & 0,753 & 0 \\
Competitive Advantage & 0,043 & 0,206 & 0,453 \\
\hline Indirect Effects & 0 & 0 & 0 \\
Innovation & 0,033 & 0,342 & 0 \\
Competitive Advantage & & & 0 \\
\hline Total Effects & 0,074 & 0,753 & 0,453 \\
Innovation & 0,076 & 0,547 & \\
Competitive Advantage & & &
\end{tabular}

Source: the results of data processing using AMOS 20

From the result of the measurement of the influence of exogenous variables on endogenous variables either directly or through intervening variable, it is clear that creative people play an essential role in the emergence of innovation in the business unit of batik and woven fabric that is equal to $75 \%$. Even to the competitive advantage, creative people are proven to give a relatively big influence (55\%) than the influence of other exogenous variables (in this study is the technology variable). Variable of creative people will contribute greatly to the value of competitive advantage if it is mediated by innovation. Directly, creative people will only affect $21 \%$ to competitive advantage, while creative people who bring up the innovation will be able to increase competitive advantage about $34 \%$.

Testing the hypotheses proposed in this study also shows the following results:

Table 3. Hypotheses Test Result

\begin{tabular}{lrrrrr}
\hline & Estimate & S.E. & C.R. & P & Label \\
\hline INN $\leftarrow$ CP &, 852 &, 148 & 5,740 & $* * *$ & Significant \\
INN TECH &, 072 &, 115 &, 625 &, 532 & Not Significant \\
CA $\leftarrow$ INN &, 315 &, 143 & 2,206 &, 027 & Significant \\
\hline
\end{tabular}

It can be seen from the table above that creative person with $\mathrm{p} \leq 0.05$ have a positive and significant effect on the emergence of creative ideas as the foundation of creativity in the innovation process in batik and woven-fabric business units in Indonesia. An innovation process that takes place through culture innovation, innovation process, and product innovation is proven to have a positive and significant effect (p-value $0,027,0,0,0$ ) on competitive advantage in batik and woven fabric as sub-sector business creative industry in Indonesia. The technology factor is empirically proven to be insignificant ( $p$-value $0,532 \geq 0,05$ ) in bringing the competitive advantage directly because technology as one of the company's internal resources must go hand in hand and 
collaborate with other internal resources such as creative people and others to bring the competitive advantage of a business unit.

Furthermore, some of the research questions proposed at the beginning can be answered based on the findings obtained from the results of this study as follows:

\section{What are the characteristics, relationships, and influences of creative people both directly and indirectly in the emergence of competitive advantage in the creative industries in Indonesia?}

Creative people in Indonesia, especially those who are working in the batik and woven fabric sub-sector, have characteristics such as having open nature and willingness to share their experience so that it can create an encouraging environment in the company. Moreover, they are able to see things from different perspectives, have a sense of curiosity about something, always independent in thinking about and judging something, and also independent in action. These characteristics are ultimately able to bring the results of craft products especially batik and woven fabric of Indonesia is growing well compared with other creative sub-sector industries.

From the result of the measurement model in Figure 2, it can be seen that the relationship between creative people and technology used in Indonesian batik and woven fabric business unit is 53\% which shows a positive and quite close relationship between the two. The most significant correlation between creative people and innovation in the company is $79 \%$ which shows a positive and close relationship. Directly, the relationship between creative people and competitive advantage also shows a positive and close relationship that is equal to 59\%. All of these relationships are seen in the life of the company, where the most significant dominance in the development of business units is highly dependent on creative people who have creative ideas which continue to explore and develop the precious natural resources and culture of Indonesia into product designs and batik and woven-fabric production process.

The influence of creative people indirectly through innovation on competitive advantage was much more considerable and quite significant (34\%) compared to the direct influence of creative people on the competitive advantage of batik and woven fabric in Indonesia (21\%). This is because creative ideas from the creative people must be put into various innovations as a result of creativity that they create, then it can affect the competitive advantage of batik and woven fabric as a business unit in Indonesia.

\section{What are the characteristics, relationships, and the influence of technology both directly and indirectly on the emergence of competitive advantage in creative industries in Indonesia?}

The technological characteristics implemented and developed in the Indonesian batik and woven-fabric business unit are moderate, which is not very conventional nor modern. The use of hard technology such as woven machines and others is not too sophisticated. Also, the use of updated soft technology has not been implemented. Most business units implement an integrated quality management system, although in reality it has not been applied thoroughly in the company. The use of computer-based technology seems to have been widely used in several business units of Indonesian batik and woven-fabric, especially in the range of online-based product marketing.

It can be concluded from the result of the measurement model in Figure 2, that the percentage of the relationship between technology and innovation is $47 \%$ and indicates a positive and quite close relationship. On the contrary, the relationship between technology with a competitive advantage is 36\%; it is relatively small and not 
close. It clearly shows that technology is a technical tool in the realization of innovation in order to bring competitive advantage to a company.

Surprisingly, the effect of technology on competitive advantage, either directly or indirectly through innovation, did not show a significant difference (only 1\% was different). This shows that the use of technology in the operation of batik and woven fabric business unit of Indonesia as one of the company's resources always has to go hand in hand with other resources such as creative people and others. Hopefully, it will be able to produce an innovation that brings competitive advantage to the company.

\section{How is the relationship and influence of innovation on the sustainable competitive advantage, and how significant is characteristic of innovation in developing Indonesian creative industry?}

Innovation has a positive and relatively close relationship (64\%) with the emergence of competitive advantages of Indonesian batik and woven fabric business unit, and it has empirically proven that innovation can influence the competitive advantage of batik and woven-fabric business unit directly by $45 \%$. The characteristics of innovation that craftsmen of batik and woven-fabric in Indonesia do are product innovation and process innovation such as the use of various raw materials sourced directly from the natural resources from several islands in Indonesia. Thus, they do produce not only unique products but also undergo a unique process in the production stage. Also, the innovation climate within the business unit is very beneficial and becomes a culture that is automatically inherited in every cycle of the Indonesian batik and woven-fabric business unit, which continues to explore and present the products that are promoting the plentiful of Indonesian heritage and culture.

\section{What economic value is significant and emerges as a competitive advantage for creative industries in Indonesia?}

Some business units of craft sub-sector, especially Indonesian batik and a wovenfabric business unit which become part of the analysis in this research empirically show a competitive advantage for both company and products they produce, both at national and international level. Some of the strengths of Indonesian batik and woven-fabric business units observed show unique characteristics such as:

The Indonesian batik and woven-fabric business units can exploit opportunities that exist outside the company's environment, such as opportunities on the availability of raw materials that can be obtained directly from Indonesia's rich and diverse natural and cultural resources. In addition, opportunities that come from foreign countries such as foreign tourists who deliberately come directly to Indonesia to buy handicraft products produced by business units in the craft sub-sector as one of Indonesia's creative industries. These opportunities can further be utilized by Indonesian batik and wovenfabric business units in production.

Indonesian batik and woven-fabric business units are spread in several cities and provinces. They give priority to local traditions and heritage which are then displayed in various batik and woven-fabric products of each region in order to promote good products that have local cultural nuances. This is the next characteristic of the competitive advantage of batik and woven-fabric business units in Indonesia, which can create unique products, hard to imitate, and rarely produced by similar business units due to principles in the development of a local wealth of each region in Indonesia. 


\section{CONCLUSION}

In fact, fifteen creative industry sub-sectors that currently have the potential to be developed as superior sub-sectors that can enhance competitiveness and high creative economic growth experience do not include all of them. Only three out of 12 the creative industry sub-sectors can contribute to the national GDP. They are craft, fashion, and culinary.

After conducting survey research in craft business unit, as one of the sub-sectors of creative industry, precisely in 30 units of batik and woven-fabric business in 6 provinces in Indonesia, the author found that the craft sub-sector is able to contribute well because it has creative people who always have creative ideas that enable them to innovate products. To innovate means exploring and utilizing local resources in the form of nature, culture, and local traditions which are then realized into products that become their pride and characterizes the local cultural heritage.

This has resulted in a significant impact on the increasing competitive advantage of the Indonesian batik and woven business unit, as several business units observed indicate the ability to create values of excellence in competition among others the increased ability to respond to various opportunities that come both from local and international regions as well. In addition, some business units demonstrate a much better product creation capability. They are capable of creating products that are unique and hard to imitate. The products are created by business owners from different places as they innovate in the basis of local natural resources such as raw materials, culture, and tradition so that it gives its competitive power for the business unit in batik and traditional woven-fabric as the sub-sector of creative industry in Indonesia.

\section{REFERENCES}

Ardhala, A. D., Santoso, E. B. and Sulistyarso, H. (2016). "Influence Factors on the Development of Creative Industry as Tourism Destination (Case Study: Footwear Village in Mojokerto City)". Procedia - Social and Behavioral Sciences. Vol. 227, pp 671-679.

Arifin, A. and Sugiyanto, F. (2015). "Value Chain Model of Plasma Core Partnership of Hair Production Creative Industry in Purbalingga Regency, Central Java Province". Procedia - Social and Behavioral Sciences. Vol. 211, pp 10-18.

Aritenang, A. (2015). "Transfer Policy on Creative City: The Case of Bandung, Indonesia". Procedia - Social and Behavioral Sciences. Vol. 184, pp 40-45.

Barney, J. B. (1991). "Firm resources and sustained competitive advantage". Journal of Management. Vol. 17 No. 1, pp 99-120.

Barney, J. B. and Hesterly, W. S. (2015). Strategic Management and Competitive Advantage Concepts and Cases. Pearson

Batsakis, G. and Mohr, A. T. (2016). "Revisiting the relationship between product diversification and internationalization process in the context of emerging market MNEs". Journal of World Business. Vol. 52 No. 4, pp 564-577.

Baum, M., Schwens, C. and Kabst, R. (2015). "A latent class analysis of small firms' internationalization patterns". Journal of World Business. Vol. 50 No. 4, pp 754-768.

Bell, J., Crick, D. av. and Young, S. (2004). "Small firm internationalization and business strategy: an exploratory study of "knowledge-intensive" and "traditional" manufacturing firms in the UK". International Small Business Journal. Vol. 22 No. 1, pp 23-56. 
Gunarto, M. (2013) Membangun Model Persamaan Struktural (SEM) dengan Program Lisrel (Pertama). Tunas Gemilang Press.

Hair, J. F., Black, W. C., Babin, B. J. and Anderson, R. E. (2014). “Multivariate Data Analysis. Prentice-Hall, Inc". Vol. 1, pp 433.

Howkins, J. (2002). The Creative Economy: How People Make Money from Ideas. Penguin.

Hutabarat and Zoel. (2012). "The Potential Growth of Creative Industries in Province of Riau". Procedia - Social and Behavioral Sciences. Vol. 65, pp 839-844.

Kamprath, M. and Mietzner, D. (2015). "The impact of sectoral changes on individual competencies: A reflective scenario-based approach in the creative industries". Technological Forecasting and Social Change. Vol. 95, pp 252-275.

Kementerian Pariwisata dan Ekonomi Kreatif RI. (2014). KEKUATAN BARU INDONESIA MENUJU 2025.

Murphy, S. E. (2016). "Leadership Lessons from Creative Industries: The Case of Producers, Directors, and Executives in Film and Television". Monographs in Leadership and Management. Vol. 8, pp 243-273.

Parkman, I. D., Holloway, S. S., \& Sebastiao, H. (2012). “Creative industries: aligning entrepreneurial orientation and innovation capacity". Journal of Research in Marketing and Entrepreneurship. Vol. 14 No. 1, pp 95-114.

Pink, D. H. (2005). Whole New Mind: Moving from the Information Age to the Conceptual Age. Riverhead Books.

Utami, R. M. and Lantu, D. C. (2014). "Development Competitiveness Model for SmallMedium Enterprises among the Creative Industry in Bandung". Procedia - Social and Behavioral Sciences. Vol. 115, pp 305-323.

Wiryono, S. K., Susatyo, H., Utomo, S., Suryanta, B., Sudrajad, O. Y., Lazuardi, K. M. and Yuanita, H. (2015). "Risk Mapping on Dynamics Creative Industry: Case Study at Bandung City, Indonesia”. Procedia - Social and Behavioral Sciences. Vol. 169, pp 125130. 